\title{
College Library Standards: Questions and Answers
}

In 1959 the American Library Association promulgated its first, and only, set of "Standards for College Libraries." These standards have served the higher education community in a number of important ways over the past decade and a half, but they have also become increasingly inadequate to deal with changes in academic library operation and responsibility. Accordingly the association has recently appointed a committee to revise the standards into accord with present and anticipated needs of higher education.

The following questions and answers are designed to acquaint interested individuals and agencies with some of the key considerations and problems in the development of college library standards.

$Q$. What is the purpose of library standards?

A. Library standards may be variously interpreted as the pattern of an ideal, as a model procedure, as a stimulus for future development and improvement, as a measure for appraisal, and as an instrument to assist decision and action not only by librarians but also by laymen concerned with the institution, planning, and administration of library services. Although it may be expected that the standards now being developed will be understood in all of these ways and for all of these purposes, their main thrust will be to provide a means for assessing the adequacy of college libraries.

$Q$. Can a single set of standards be made to apply to all institutions of higher education?

A. Probably not. For that reason the committee has defined its purview as comprising only those libraries that serve liberal arts programs at the baccalaureate and master's degree levels and those granting fewer than ten doctorates annually. Two-year colleges, larger universities, independent professional schools, and foreshortened or truncated specialized programs are not included in the work of this committee.

Q. But there is great heterogeneity even within the group of institutions which the committee does include in its work. Can one set of standards be made to apply even to them?

A. The committee believes that it can, if the standards are so structured as to base the requirements of each library individually upon the specific objectives and programs of the institution it serves.

Q. But will that not require a different set of standards for every institution?

A. Ostensibly, yes, but practically, no. The qualitative aspects of the standards can be virtually the same for all institutions in the group, regardless of institutional objectives; a certain minimum level of library quality must exist before any college can be allowed to grant a degree, and that level can be stated once for all. Quantitative aspects of the standards, on the other hand, will have to take into account such institutional uniqueness as size of faculty and student body, breadth and depth of academic program, and kinds of degrees offered. The committee plans to relate quantitative requirements to institutional objectives by formula or percentile within homogeneous subsets of institutions.

$Q$. It appears therefore that the revised standards will contain both qualitative and quantitative elements.

A. Yes, although in dealing with certain aspects of library service quality and quantity are separable only in theory: it is possible to have quantity without quality; it is not possible to have quality without quantity defined in relation to the purposes of the institution.

$Q$. What aspects of the standards can, in this view, be quantified?

A. Size of collection, size of staff, and size of library building.

Q. But you do not say anything about "outputs." Cannot the standards require a certain specified level of "productivity" of some sort?

A. Not at this time. Although there has been some promising recent research into library productivity, it is still too spotty and too lacking in consensual support to permit it to be written into a standard. We do know from experience, however, that adequate library "outputs" cannot take place without certain minimal "inputs," and those inputs will be quantified.

Q. But cannot the committee answer some of these and other basic questions?

A. No, the committee has none of the resources necessary to engage in original research. The research deficit regarding college libraries, moreover, is so vast as to require still a good many years of basic study in libraries and library schools and widespread discussion and debate in the library forums before such standards can be prepared. Most good librarians have opinions about productivity, some supported by facts, but these beliefs do not yet represent adequate agreement for purposes of standards making.

$Q$. If the committee is not going to answer such questions, what then will it do?

A. The committee will attempt to bring together and to articulate in its draft the aggregate experience and judgment of the academic library profession as regards requisite resources, services, and facilities adequate for a minimal library program in a college.

Q. How will the standards be enforced?

A. The American Library Association, ex- 
cept in the matter of library education, has never considered its responsibility as extending to the enforcement of stiundards. Rather it makes standards available for use by enforcement agencies. Government agencies, accrediting associations, and professional organizations may enforce these standards if they choose. In addition, of course, the ALA lends its very substantial moral suasion to the standards which it promulgates, so that they are frequently used for purposes of self-evaluation and comparison. It is for this reason that they must represent the consensus of the library profession.

Q. How has the committee decided what elements the standards should contain?

A. The committee reviewed the work of all of the regional accrediting agencies, many of the professional associations, and a large number of experienced library surveyors and educators to determine the range of elements which have been found useful in evaluating college libraries, and it is including these elements in its standards.

Q. But higher education is changing so rapidly. How can standards be written which can accommodate such rapid changes?

A. The committee has also attempted to review all responsible speculation regarding higher education in the next decade or two, and that research will be reflected in its draft. It will

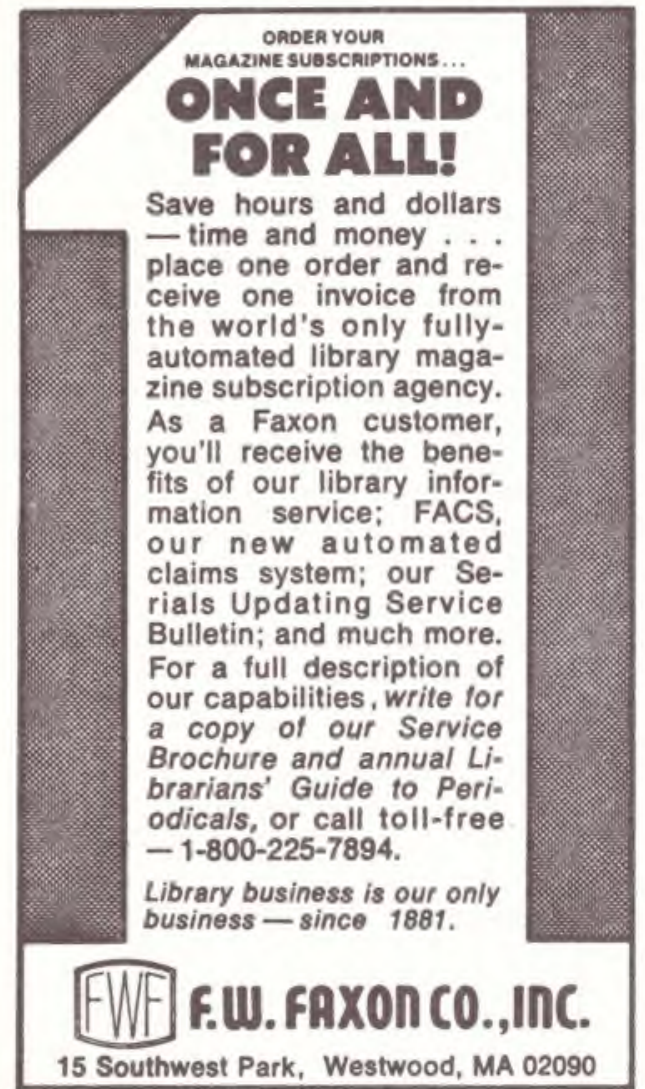

also reflect the committee's interpretation of likely innovations in library technology and of changes in the social, political, and fiscal environments in which college libraries work. To the degree that its interpretations and assumptions are valid, the resulting standards will be either long- or short-lived, but sooner or later they will have to be rewritten again. The existing standards have served usefully for fifteen years, and the committee hopes that the revision now being made will serve for at least an equal period.

The members of the committee are Johnnie Givens, Austin Peay State University; David Kaser, Graduate Library School at Indiana University; Arthur Monke, Bowdoin College; David Perkins, California State University at Northridge; James Pirie, Lewis \& Clark College; Jasper Schad, Wichita State University; and Herman Totten, School of Librarianship at the University of Oregon. The work of the committee has been supported by two J. Morris Jones-World Book Encyclopedia-ALA Goals Awards. The first draft of the revision will be published in December 1974. Hearings on that draft will be held during the ALA Midwinter Meeting, January 20-21, 1975, in Chicago. -

Reprints of this article are available from the ACRL office, 50 E. Huron St., Chicago, IL 60611.

\section{LIBRARIAN AND}

\section{FRANCISCAN}

Librarians attracted to the Franciscan way of life may become Franciscan Friars as brothers or priests and function professionally as librarians at the high school, college/university, or seminary level.

\section{Write:}

Franciscan Vocation Office

600 Soundview Ave.

Bronx, N.Y. 10473 